\title{
Critical illness-related corticosteroid insufficiency in patients with low cardiac output syndrome after cardiac surgery
}

\author{
JY Lim*, SH Jung, JB Kim, SJ Choo, CH Chung, JW Lee \\ From ESICM LIVES 2015 \\ Berlin, Germany. 3-7 October 2015
}

\begin{abstract}
Introduction
Low cardiac output syndrome (LCOS) which features classic symptoms of hypotension, tachycardia, oliguria and poor peripheral perfusion after cardiac surgery is not rare in the immediate postoperative period, and usually requires high dose of inotropes and volume replacement. In this setting of critical illness and stress, Critical Illness-Related Corticosteroid Insufficiency (CIRCI) may occur and aggravate hemodynamic instability. However, lack of evidence or guideline exists regarding diagnostic criteria of CIRCI in LCOS or use of steroids.
\end{abstract}

\section{Objectives}

We aimed to investigate clinical features of CIRCI in patients with LCOS after cardiac surgery and assessed the efficacy of steroid use in this subset of patients.

\section{Methods}

We retrospectively reviewed the patients who were suspected as combined CIRCI in the setting of LCOS after cardiac surgery between February 2010 and September 2014. Diagnosis of CIRCI was made by a delta total serum cortisol of $<9 \mu \mathrm{g} / \mathrm{dL}$ after ACTH $250 \mu \mathrm{g}$ administration or a random total cortisol of $<10 \mu \mathrm{g} / \mathrm{dL}$. Patients who were exposed to steroids before surgery for any medical causes were excluded.

\section{Results}

28 patients underwent adrenocorticotropic hormone (ACTH) stimulation test in suspicion of CIRCI. Among them, 20 patients met the diagnostic criteria. Mean age was $63.8 \pm 12.4$ years. Majority of patients $(80 \%)$ underwent valvular surgeries or pericardiectomy. Patients who were diagnosed with CIRCI (+) showed higher Sequential Organ Failure Assessment (SOFA) score at the time of diagnosis compared to CIRCI $(-)$ patients $(16.1 \pm 2.3$ versus $11.4 \pm 3.5, \mathrm{p}=0.001)$ and higher total bilirubin level $(11.7 \pm 9.2 \mu \mathrm{mol} / \mathrm{L}$ versus $4.9 \pm 4.3 \mu \mathrm{mol} / \mathrm{L}, \mathrm{p}=$ 0.015). Glasgow Coma Scale (GCS) score was lower in CIRCI $(+)$ group $(7.9 \pm 3.9$ versus $11.2 \pm 3.2, \mathrm{p}=$ 0.048). 3 patients $(10.7 \%)$ died only in CIRCI $(+)$ group without statistical significance. Among CIRCI $(+)$ patients, only 6 patients (30\%) received glucocorticoid therapy at surgeon's discretion. Initial dose of steroid therapy varied from 50 to $240 \mathrm{mg}$ per day. Main reason not to use steroid to the other patients was the concern of infection. Mean blood pressure was elevated by the average of $22.2 \pm 8.7 \mathrm{mmHg}$ after steroid therapy and duration of inotropic support was significantly shorter in steroid therapy group compared to non-steroid therapy group $(4.1 \pm 2.3$ versus $30 \pm 22.8$ days, $\mathrm{p}=0.001)$. Infection developed in 3 patients $(15 \%)$ only in nonsteroid therapy group without significant difference.

\section{Conclusions}

Critical Illness-Related Corticosteroid Insufficiency should be suspected in patients with Low cardiac output syndrome after cardiac surgery especially when patients shows signs of persistent multi-organ failure such as high SOFA score or total bilirubin level. Glucocorticoid replacement therapy may be considered in patients with Critical Illness-Related Corticosteroid Insufficiency after cardiac surgery to reduce the use of inotropes without increasing additional infection risk. 

surgery. Intensive Care Medicine Experimental 2015 3(Suppl 1):A546.

\section{Submit your manuscript to a SpringerOpen ${ }^{\circ}$ journal and benefit from:}

- Convenient online submission

- Rigorous peer review

- Immediate publication on acceptance

- Open access: articles freely available online

- High visibility within the field

- Retaining the copyright to your article

Submit your next manuscript at $\gg$ springeropen.com 